\title{
Nutrition and growth of potted gerbera according to mineral and organic fertilizer ${ }^{(1)}$
}

\author{
FRANCIELLY TORRES DOS SANTOS(2); FERNANDA LUDWIG ${ }^{(3)}$; \\ LUIZ ANTONIO DE MENDONÇA COSTA ${ }^{(2)}$ e MÔNICA SAROLLI SILVA DE MENDONÇA COSTA ${ }^{(2)}$
}

\begin{abstract}
In order to meet the growing market of gerbera, it is necessary to develop studies that maximize its production, especially using organic fertilizer. In order to assess the nutrition and growth of potted gerbera conducted with mineral and organic fertilization, an experiment in a greenhouse was done, located at Western Paraná State University, Brazil. The experimental design was made in randomized blocks, with four replications and five treatments. The treatments were defined according to the source of fertilization, mineral (NPK) or organic. The organic fertilization were obtained by diluting in water four organic compost of poultry slaughter waste, obtained from in the composting process, in order to adjust electrical conductivity. The solution of the compost was used as organic fertigation, making the organic treatments. The liquid organic fertilizer, as well as irrigation of mineral treatment, was performed manually once a day. At the end of vegetative and reproductive periods, the levels of $\mathrm{N}, \mathrm{P}, \mathrm{K}, \mathrm{Ca}, \mathrm{Mg}$ and Fe were quantified in the plant tissue. At the same time, biometric parameters were assessed (number of leaves, plant diameter, leaf area, dry matter of aerial parts, number of heads, inflorescence dry matter, stem height, head diameter and diameter stem). The liquid organic fertilizers, obtained by composting procession of poultry slaughter waste, can be used as alternative source for potted gerbera nutrition, since they provide better or higher culture growth than the mineral fertilizer.
\end{abstract}

Keywords: Gerbera jamesonii, Asteraceae, floriculture, nutritional states.

\section{RESUMO}

Nutrição e crescimento de gérbera envasadas em função da adubação mineral e orgânica

Visando a atender ao mercado crescente de gérberas, torna-se necessário o desenvolvimento de estudos que maximizem sua produção, destacando-se a adubação orgânica. Com o objetivo de avaliar a nutrição e o crescimento de gérbera de vaso conduzida com adubação mineral e orgânica, realizou-se um experimento em estufa agrícola, localizada na Universidade Estadual do Oeste do Paraná, Brasil. O delineamento experimental foi em blocos casualizados com quatro repetições e cinco tratamentos. Os tratamentos foram definidos em função da fonte da adubação, mineral (NPK) ou orgânica. As adubações orgânicas foram obtidas pela diluição em água de quatro compostos orgânicos provenientes do processo de compostagem de resíduos do abate de frangos. A solução dos compostos foi utilizada como fertirrigação orgânica, perfazendo os tratamentos orgânicos. Ao final do período vegetativo e reprodutivo foram quantificados no tecido vegetal, os teores dos nutrientes N, $\mathrm{P}$, $\mathrm{K}, \mathrm{Ca}, \mathrm{Mg}$ e Fe. Foram avaliados na mesma época os parâmetros biométricos (número de folhas, diâmetro de planta, área foliar, matéria seca da parte aérea, número de capítulos, matéria seca da inflorescência, altura de haste, diâmetro de capítulo e diâmetro de haste). Os adubos orgânicos líquidos, obtidos por meio da compostagem de resíduos de abate de aves, podem ser usados como fonte alternativa para a nutrição de gérbera envasada, uma vez que proporcionam melhor ou maior crescimento da cultura quando comparadas a adubação mineral.

Palavras-chave: Gerbera jamesonii, Astereceae, floricultura, estado nutricional.

\section{INTRODUCTION}

Gerbera (Gerbera jamesonii) is an herbaceous ornamental plant belonging to the family Asteraceae (CARDOSO and SILVA, 2013). Leaves are arranged in a rosette shape and the petiole of some of them evolves floral buds that develop peduncles with terminal inflorescence in the head (INFOAGRO, 2014). It is commercially grown as cut flower and potted. In recent years, its commercial cultivation has become of great economic importance for the floriculture (GUERRERO et al., 2012), standing out as a promising market, especially for the wide range of available shapes and colors (LONGCHAR and KEDITSU, 2013).

The substrate for planting gerbera should have good drainage, since the plant does not tolerate much water. The substrate fertility level should be medium to high and slightly acidic $\mathrm{pH}$. Use organic fertilizer or mineral fertilizer, NPK combination in the proportion 4-10-8 (STANCATO, 2014). In order to meet this growing demand, it is necessary to

\footnotetext{
(1) Trabalho recebido para publicação em 02/03/2015 e aprovado em 08/06/2015

(2) Universidade Estadual do Oeste do Paraná (UNIOESTE), Centro de Ciências Exatas e Tecnológicas, Cascavel-PR, Brazil. *Corresponding author: francielly_torres@hotmail.com

(3) Universidade Estadual do Rio Grande do Sul (UERGS), Unidade em Santa Cruz do Sul. Santa Cruz do Sul-RS, Brazil.
} 
develop studies that maximize its production, especially using organic fertilizer. An alternative to potted gerbera nutrition is the use, via fertigation, organic compost from agro-industrial waste composting process (CASTRO et al., 2010).

However, the use of organic compost requires care, because they can cause excessive acidity and/or salinity in the soil or substrate, besides generating nutritional stress in the plant, resulting on excess or deficiency of nutrients according to applied doses. The salinity of organic compost may be high because these are obtained from a waste rich in nutrients (HERNÁNDEZ et al., 2010; MOTA et al., 2011). Thus, it is necessary to take some precautions in its use (CABALLERO et al., 2009). Therefore, the dilution of organic compost in water, referred to as liquid organic fertilizer, is presented as one way of meeting nutritional needs of gerbera culture through fertigation, without, however, raising the salinity to potentially toxic levels by controlling electrical conductivity.

Because of the concern about the correct destination of residues generated in agricultural production chains, together with the possibility of producing flowers with quality at competitive prices, the number of scientific papers with this approach has risen in Brazil (RUPPENTHAL and CASTRO, 2005; MEDEIROS et al., 2007; CASTRO et al., 2008). However, it is still necessary to study organic forms of nutrition in order to guarantee the fertilization of gerbera culture without causing toxic symptoms or disability.

Potted gerbera plants are moderately demanding in nutrition (LUDWIG et al., 2010). As a result, it is important to adjust fertility levels avoiding the yellowing of leaves due to poor nutrition, as well as excessive growth and delayed flowering due to excessive nutrition. The moderate level of fertility produces plants with a proportional ratio of leaf area and inflorescence (JEONG et al., 2009, LUDWIG et al., 2015), an important feature for potted flowers. Given potted culture commercialization potential, this study was developed in order to assessing the nutrition and growth of gerbera plants with mineral and organic fertilizers.

\section{MATERIAL AND METHODS}

The experiment was conducted in the months of September to December of 2011. During the experimental period, the average temperature within the greenhouse was $29.5^{\circ} \mathrm{C}$ and the average relative air humidity was $58.5 \%$. The greenhouse has an arch structure, with the side and the clear plastic cover with 150 microns, over an area of $96.0 \mathrm{~m}^{2}$ (8.0 m wide, $12.0 \mathrm{~m}$ long) and $2.6 \mathrm{~m}$ of height. To ensure uniformity of light intensity and transmission of diffuse light inside the greenhouse, a thermal reflector mesh (Aluminet ${ }^{\circledR}$ ) with $30 \%$ shading was internally set. Experimental design with randomized blocks, five treatments, four replications, six pots per plot, and one plant per pot was made, making a total of 30 sampling units per block and 120 pots in total. The treatments were defined according to their fertilization, one mineral fertilizer and four organic.

The treatment with mineral fertilizer, called treatment $1\left(\mathrm{~T}_{1}\right)$, was performed every 15 days, with $5.0 \mathrm{~g}$ per pot with 4-10-8 formula (STANCATO, 2014), using 0.2 $\mathrm{g}$ of ammonium sulfate $\left(\left(\mathrm{NH}_{4}\right)_{2} \mathrm{SO}_{4}-21 \% \mathrm{~N}\right) ; 0.4 \mathrm{~g}$ of superphosphate $\left(\mathrm{P}_{2} \mathrm{O}_{2}-18 \% \mathrm{P}\right) ; 0.3 \mathrm{~g}$ of potassium chloride ( $\mathrm{KCl}-61 \% \mathrm{~K})$.

The liquid organic fertilizers were obtained from the dilution of organic compost resulting from agro-industrial wastes composting process. The initial composition (before composting) of each treatment was as follows: $T_{2}(145 \mathrm{~kg}$ of corn residue, $80 \mathrm{~kg}$ of hatchery waste, $30 \mathrm{~kg}$ of sludge flotation, $50 \mathrm{~kg}$ of wheat husks, $20 \mathrm{~kg}$ of cellulosic casings, $90 \mathrm{~kg}$ of solid fraction of pig manure, $25 \mathrm{~kg}$ of remaining coal from boiler, $30 \mathrm{~kg}$ of remaining ash from boiler and 30 $\mathrm{kg}$ of solid fraction of waste from truck washing); $\mathrm{T}_{3}(50$ $\mathrm{kg}$ of corn waste, $70 \mathrm{~kg}$ of hatchery waste, $50 \mathrm{~kg}$ of sludge flotation, $50 \mathrm{~kg}$ of wheat husks, $110 \mathrm{~kg}$ of cellulosic casings, $45 \mathrm{~kg}$ of solid fraction of pig manure, $30 \mathrm{~kg}$ remaining ash from boiler, $45 \mathrm{~kg}$ of solid fraction of waste from truck washing and $50 \mathrm{~kg}$ of stock plant); $\mathrm{T}_{4}$ (40 kg of hatchery waste, $45 \mathrm{~kg}$ of sludge flotation, $50 \mathrm{~kg}$ of cellulosic casings, $100 \mathrm{~kg}$ of solid fraction of pig manure, $70 \mathrm{~kg}$ of remaining coal from boiler, $80 \mathrm{~kg}$ remaining ash from boiler, $15 \mathrm{~kg}$ of solid fraction of waste from truck washing and $100 \mathrm{~kg}$ of sugarcane bagasse); $\mathrm{T}_{5}$ (35 kg of hatchery waste, 35 $\mathrm{kg}$ of sludge flotation, $75 \mathrm{~kg}$ of cellulosic casings, $75 \mathrm{~kg}$ of solid fraction of pig manure, $30 \mathrm{~kg}$ of remaining coal from boiler, $150 \mathrm{~kg}$ of remaining ash from boiler, $15 \mathrm{~kg}$ of solid fraction of waste from truck washing, $10 \mathrm{~kg}$ of stock plant and $75 \mathrm{~kg}$ of sugarcane bagasse). Each composting windrow was made with $500 \mathrm{~kg}$ (natural matter) of agroindustrial wastes.

At the end of the composting process, organic compost with high electrical conductivity (EC) of 5.63; 8.29; 3.63 and $5.46 \mathrm{dS} \mathrm{m}^{-1}$, for $\mathrm{T}_{2}, \mathrm{~T}_{3}, \mathrm{~T}_{4}$ and $\mathrm{T}_{5}$, respectively, were generated, limiting their use as substrates for the production of potted gerbera. Then, a dilution of the organic compost in order to use only the liquid fraction of fertigation for culture was performed. After dilution, nutrient solutions with EC $0.56 ; 0.51 ; 0.36$ and $0.27 \mathrm{dS} \mathrm{m} \mathrm{m}^{-1}$ were obtained in the growing period for $\mathrm{T}_{2}, \mathrm{~T}_{3}, \mathrm{~T}_{4}$ and $\mathrm{T}_{5}$, respectively, and $1.52 ; 1.38 ; 0.97$ and $0.73 \mathrm{dS} \mathrm{m}^{-1}$ for $\mathrm{T}_{2}, \mathrm{~T}_{3}, \mathrm{~T}_{4}$ and $\mathrm{T}_{5}$, respectively, in the reproductive period.

The dilution was based on potassium nutrient. After dilution tests, the quantity of $27 \mathrm{~kg}$ of each of the organic composts, placed in barrels of $100 \mathrm{~L}$, was established. This solution was stirred by hand every day, during 60 days. After this period, the solution was filtered and only the liquid phase was used, phase known as liquid organic fertilizer (LOF). LOF was chemically characterized (Table 1). Total nitrogen was quantified by means of digestion in distiller Kjedahl (MALAVOLTA et al., 1997). Other macronutrients and micronutrients were determined according to the methodology of EMBRAPA (2009). 
Table 1. Chemical composition of liquid organic fertilizers (LOF) after dilution for fertigation in vegetative and reproductive periods.

Tabela 1. Composição química dos adubos orgânicos líquidos (AOL) após a diluição para fertirrigação nos períodos vegetativo e reprodutivo.

\begin{tabular}{|c|c|c|c|c|}
\hline \multicolumn{5}{|c|}{ Vegetative period } \\
\hline Macronutrients & LOF 1 & LOF 2 & LOF 3 & LOF 4 \\
\hline & \multicolumn{4}{|c|}{ - } \\
\hline $\mathrm{N}$ & $7,200.00$ & $4,700.00$ & $2,400.00$ & $3,000.00$ \\
\hline $\mathrm{P}$ & 0.04 & 0.02 & 0.02 & 0.01 \\
\hline K & 105.00 & 105.00 & 105.00 & 105.00 \\
\hline $\mathrm{Ca}$ & 159.53 & 118.88 & 99.05 & 47.48 \\
\hline $\mathrm{Mg}$ & 25.78 & 14.80 & 19.00 & 15.51 \\
\hline \multicolumn{5}{|l|}{ Micronutrients } \\
\hline $\mathrm{Na}$ & 59.27 & 51.10 & 120.18 & 30.81 \\
\hline $\mathrm{Cu}$ & 0.19 & 0.01 & 0.04 & 0.05 \\
\hline $\mathrm{Fe}$ & 20.07 & 17.08 & 11.50 & 5.72 \\
\hline $\mathrm{Mn}$ & 0.32 & 0.63 & 0.03 & 0.08 \\
\hline $\mathrm{Zn}$ & 0.71 & 0.68 & 1.29 & 0.15 \\
\hline \multicolumn{5}{|c|}{ Reproductive period } \\
\hline Macronutrients & LOF 1 & LOF 2 & LOF 3 & LOF 4 \\
\hline & \multicolumn{4}{|c|}{ 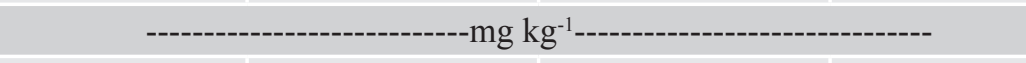 } \\
\hline $\mathrm{N}$ & $23,000.00$ & $21,600.00$ & $13,500.00$ & $14,700.00$ \\
\hline $\mathrm{P}$ & 0.11 & 0.09 & 0.13 & 0.08 \\
\hline $\mathrm{K}$ & 285.00 & 285.00 & 285.00 & 285.00 \\
\hline $\mathrm{Ca}$ & 432.79 & 542.68 & 538.61 & 260.27 \\
\hline $\mathrm{Mg}$ & 70.08 & 67.57 & 82.26 & 84.85 \\
\hline \multicolumn{5}{|l|}{ Micronutrients } \\
\hline $\mathrm{Na}$ & 160.79 & 233.28 & 653.45 & 168.55 \\
\hline $\mathrm{Cu}$ & 0.51 & 0.05 & 0.23 & 0.30 \\
\hline $\mathrm{Fe}$ & 54.45 & 77.90 & 67.83 & 31.31 \\
\hline $\mathrm{Mn}$ & 0.87 & 2.91 & 0.17 & 0.44 \\
\hline $\mathrm{Zn}$ & 1.93 & 3.11 & 7.04 & 0.86 \\
\hline
\end{tabular}

The experimental unit consisted of a plastic pots number 14, filled with $900 \mathrm{ml}$ of commercial substrate. The commercial substrate consisted of pine bark, peat and vermiculite, fertilized with simple superphosphate and potassium nitrate, as indicated by the manufacturer. The chemical characteristics of the substrate were: EC 0.5 $\mathrm{dS} \mathrm{m}{ }^{-1}$; pH 5.8 (TEDESCO et al., 1995); macronutrients (g kg-1): N 0.06; P 0.001; K 0.06; Ca 0.55; Mg 0.28 and micronutrients $\left(\mathrm{mg} \mathrm{kg}^{-1}\right)$ : $\mathrm{Na} 575.47 ; \mathrm{Cu} \mathrm{0.27;} \mathrm{Fe}$ 275.27; Mn 3.587; and Zn 4.08 (EMBRAPA, 2009). The physical characteristics of the substrates provided by the manufacturer were as follow: $60 \%$ humidity, water retention capacity of $130 \%$, and wet density of $500 \mathrm{~kg} \mathrm{~m}^{-3}$.

Seedlings of gerbera (Gerbera jamesonii), Florist Red Black cultivar, acquired in trays from Ball ${ }^{\circledR}$ Horticultural do Brasil Ltda., were used. The seedlings had four definitive leaves at transplantation and were acclimated for 15 days, irrigated only with water. After this period, mineral fertilizer and organic fertigations began.

Irrigation of mineral treatment and fertigation of organic treatments were carried out according to daily weighing of the pots, considering daily evaporation. The pots were then kept with $70 \%$ water retention capacity in the vegetative period and $80 \%$ in the reproductive period. The maximum amount of available water in the substrate was defined based on its water retention capacity, measured from the weighing of 10 pots per block. Irrigation and fertigation were performed manually using graduated containers, on an average of $120 \mathrm{~mL}$ vessel $^{-1}$ day $^{-1}$. The pots were arranged on wooden tables without spacing. After overlapping of the leaves, the pots were spaced in $0.20 \times 0.20 \mathrm{~m}$. Experimental evaluation was initiated after acclimatization and the results were expressed in days after acclimatization (DAA). 
The plants were evaluated at the end of the vegetative season (28 DAA) and at the end of the reproductive period (56 DAA). The vegetative season has finished when the plants showed the first flower buds. Towards the end of reproductive period was adopted marketing point, when the flowers reached two open circles.

Levels of nitrogen $(\mathrm{N})$, phosphorus $(\mathrm{P})$, potassium $(\mathrm{K})$, calcium $(\mathrm{Ca})$, magnesium $(\mathrm{Mg})$ and iron $(\mathrm{Fe})$ in plant aerial parts were quantified according to Malavolta et al. (1997). The number of leaves (NL), the diameter of the plant (DP), leaf area (LA) and the dry matter of aerial part (DMAP) were determined. The DP was determined using a ruler graduated in millimeters, adopting two inbetween perpendicular extreme points (LUDWIG et al., 2010). For the determination of leaf area, a Leaf Area Meter Li-Cor model 3100 was used, and the result was obtained in $\mathrm{cm}^{2}$ plant ${ }^{-1}$. To determine the dry matter of aerial parts, a drying process in a heater at $65^{\circ} \mathrm{C}$ with forced air circulation was performed until constant mass was achieved.

At 56 DAA, the head number per plant (HN), the inflorescence dry matter (IDM), the stem height (SH), the head diameter (HD) and the stem diameter (SD) were quantified. The SH was measured using a ruler graduated in millimeters from the upper portion of the pot to below the inflorescence insertion. The HD and SD were measured using a digital pachymeter, $5.0 \mathrm{~cm}$ below the inflorescence insertion. IDM was obtained after drying in a heater at $65^{\circ} \mathrm{C}$, with forced air circulation, until inflorescences reached a constant weight.

Initially, an exploratory data analysis was made and the assumptions of analysis of variance were verified. Afterwards, data were subjected to analysis of variance to verify if there was any significant effect of treatments. When there was significance, a Tukey test at $5 \%$ probability was used to compare means, using the statistical program $\mathrm{R}$ (R Development Core Team, 2011).

\section{RESULTS AND DISCUSSION}

The levels of $\mathrm{P}$ at $56 \mathrm{DAA}, \mathrm{Ca}$ at $28 \mathrm{DAA}$ and $\mathrm{Mg}$ at 28 DAA were significantly influenced by fertilization (Table 2). Concerning other nutrients, no statistical differences in the levels contained in the aerial parts of gerbera grown with mineral fertilizer and liquid organic fertilizers were observed.

Table 2. Content of macro and micronutrients in the aerial parts of gerberas grown with mineral fertilizer and liquid organic fertilizer, obtained at 28 and 56 DAA.

Tabela 2. Teor de macro e micronutrientes na parte aérea de gérberas cultivadas com adubação mineral e adubações orgânicas líquidas, obtidos aos 28 e 56 DAA.

\begin{tabular}{|c|c|c|c|c|c|c|}
\hline & \multicolumn{2}{|c|}{$\mathrm{N}$} & \multicolumn{2}{|c|}{$\mathrm{P}$} & \multicolumn{2}{|c|}{$\mathrm{K}$} \\
\hline & 28 DAA & 56 DAA & $28 \mathrm{DAA}$ & 56 DAA & 28 DAA & 56 DAA \\
\hline & \multicolumn{6}{|c|}{--------- } \\
\hline $\mathrm{T}_{1}$ & 28.00 & 27.50 & 0.14 & $0.69 \mathrm{a}$ & 48.63 & 45.28 \\
\hline $\mathrm{T}_{2}$ & 28.20 & 19.00 & 0.13 & $0.51 \mathrm{~b}$ & 43.31 & 41.96 \\
\hline $\mathrm{T}_{3}$ & 30.15 & 17.40 & 0.13 & $0.53 \mathrm{~b}$ & 42.58 & 43.17 \\
\hline $\mathrm{T}_{4}$ & 31.15 & 16.60 & 0.15 & $0.46 \mathrm{~b}$ & 34.55 & 32.90 \\
\hline $\mathrm{T}_{5}$ & 30.57 & 16.50 & 0.13 & $0.52 \mathrm{~b}$ & 47.07 & 39.26 \\
\hline $\mathrm{CV}(\%)$ & 5.78 & 11.2 & 16.75 & 11.02 & 22.05 & 15.51 \\
\hline \multirow[t]{4}{*}{$\mathrm{dms}$} & 3.74 & 284.88 & 0.05 & 0.13 & 21.01 & 13.73 \\
\hline & \multicolumn{2}{|c|}{$\mathrm{Ca}$} & \multicolumn{2}{|c|}{$\mathrm{Mg}$} & \multicolumn{2}{|c|}{$\mathrm{Fe}$} \\
\hline & $28 \mathrm{DAA}$ & $56 \mathrm{DAA}$ & $28 \mathrm{DAA}$ & $56 \mathrm{DAA}$ & $28 \mathrm{DAA}$ & $56 \mathrm{DAA}$ \\
\hline & \multicolumn{6}{|c|}{ 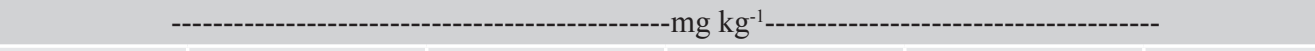 } \\
\hline $\mathrm{T}_{1}$ & $14.42 \mathrm{a}$ & 22.31 & $10.33 \mathrm{a}$ & 9.81 & 96.44 & 91.17 \\
\hline $\mathrm{T}_{2}$ & $9.23 \mathrm{bc}$ & 20.17 & $9.27 \mathrm{ab}$ & 8.27 & 93.11 & 97.03 \\
\hline $\mathrm{T}_{3}$ & $7.96 \mathrm{~cd}$ & 18.33 & $8.67 \mathrm{~b}$ & 7.37 & 114.03 & 81.95 \\
\hline $\mathrm{T}_{4}$ & $5.24 \mathrm{~d}$ & 17.18 & $8.47 \mathrm{~b}$ & 7.38 & 110.92 & 100.59 \\
\hline $\mathrm{T}_{5}$ & $12.07 \mathrm{ab}$ & 18.60 & $8.42 b$ & 8.07 & 115.93 & 64.78 \\
\hline $\mathrm{CV}(\%)$ & 17.08 & 13.75 & 16.32 & 15.52 & 11.93 & 19.23 \\
\hline $\mathrm{dms}$ & 3.65 & 5.80 & 1.45 & 2.45 & 27.48 & 94.09 \\
\hline
\end{tabular}

Averages followed by the same letter in the column do not differ on Tukey test at $5 \%$ significance level. $\mathrm{T}_{1}$ : commercial substrate: mineral fertilizer (NPK) irrigated with water. $T_{2}$ : commercial substrate fertilized with composition $T_{2}, T_{3}$ : commercial substrate fertilized with composition $\mathrm{T}_{3} \cdot \mathrm{T}_{4}$ : commercial substrate fertilized with composition $\mathrm{T}_{4} \cdot \mathrm{T}_{5}$ : commercial substrate fertilized with composition $\mathrm{T}_{5}$.

Médias seguidas pela mesma letra na coluna não diferem entre si pelo teste de Tukey ao nível de 5\% de significância. $T_{1}$ : substrato comercial: adubação mineral (NPK) irrigado com água. $T_{2}$ : substrato comercial fertirrigado com composição $T_{2}$. $T_{3}$ : substrato comercial fertirrigado com composição $T_{3}$. $T_{4}$ : substrato comercial fertirrigado com composição $T_{4} \cdot T_{5}$ : substrato comercial fertirrigado com composição $T_{5}$. 
According to Mercurio (2002), the appropriate level range for the content of $\mathrm{N}$ is 27.0 to $31.0 \mathrm{~g} \mathrm{~kg}^{-1}$. Only in the vegetative period the levels of this nutrient were near this range, whereas in the reproductive period all treatments with organic liquid fertilizer were below the recommended. Although $\mathrm{N}$ levels found in aerial parts of plants during the reproductive period, in response to organic treatments, were below the ideal indicated by the author, visually there was no deficiency of this nutrient in plants' growth and a difference on the intensity of the green color of the leaves was not observed.

Several studies in relation to $\mathrm{N}$ levels in gerbera leaves showed variations in the results. Among these, Savvas and Gizas (2002), who worked with hydroponic gerbera for cutting found average levels of $21.0 \mathrm{~g} \mathrm{~kg}^{-1} \mathrm{~N}$ in fully expanded young leaves. Zheng et al. (2004) found average levels of $35.0 \mathrm{~g} \mathrm{~kg}^{-1}$ applying concentrations of $1.7 ; 1.0 ; 0.5$ and $0.2 \mathrm{dS} \mathrm{m}^{-1}$ of nutrient solutions.

Mercurio (2002) indicates P levels in the aerial part from 1.9 to $3.5 \mathrm{~g} \mathrm{~kg} \mathrm{k}^{-1}$ as suitable for the growth of gerbera. Taking into account this range of values, regardless of the period and treatment, the levels did not reach this recommendation. Gerbera plants subjected to mineral fertilization $\left(T_{1}\right)$ presented a significantly higher $P$ value in relation to other treatments in the reproductive period $\left(0.69 \mathrm{~g} \mathrm{~kg}^{-1}\right)$. However, to reach the ideal P values for plant nutrition, the increased amount of phosphorus is indicated to avoid the low $\mathrm{P}$ content in the leaves of gerbera plants.

When P supply is limited, plants grow more roots, increase the rate of uptake by roots from the soil, retranslocate P from older leaves, and deplete the vacuolar stores of P. Conversely, when plants have appropriate $\mathrm{P}$ supply but absorbing it at rates that exceed demand, a number of processes can act to prevent the accumulation of toxic P concentrations (SCHACHTMAN et al., 1998). Barbosa et al. (2009) report that in the early development of ornamental plants the required amounts of $\mathrm{P}$ are smaller, increasing with time, coinciding with the flowering. This was observed in the present study because P levels in the vegetation period are lower when compared to the reproductive period.

Ludwig et al. (2008) found average levels of 2.3 and 2.8 $\mathrm{g} \mathrm{kg}^{-1}$ of $\mathrm{P}$ in gerbera grown in 50 and $100 \%$ concentration in nutrient solution, respectively, at 62 DAA. Likewise, Savvas and Gizas (2002) obtained values from 2.3 to 2.7 $\mathrm{g} \mathrm{kg}^{-1}$ the end of the productive period of gerbera culture.

The $\mathrm{K}$ levels in plant tissue were high, being largely above that proposed by Mercurio (2002), from 30.6 to 36.6 $\mathrm{g} \mathrm{kg}^{-1}$. However, no toxicity symptoms were observed. The culture of gerbera has a high demand for K, especially in the flowering phase (DAMASCENO et al., 2010). One reason for the high demand of $\mathrm{K}$, usually the most abundant cation in the plant, is possibly the need for high concentrations in the cytoplasm to ensure optimal enzyme activity (MALAVOLTA, 2006).

For $\mathrm{Ca}$, there was a statistical difference only in the vegetative period. The optimal value of this nutrient for growing gerbera, as indicated by Mercurio (2002), is 16.6 $\mathrm{g} \mathrm{kg}^{-1}$. Although values obtained in all treatments are below reference values, there was no deficiency symptoms in gerbera plants studied.

The Mg level in the plant tissue of gerbera fertilized with mineral fertilizer $\left(\mathrm{T}_{1}\right)$ of $10.33 \mathrm{mg} \mathrm{kg}^{-1}$, was significantly higher in relation to treatments $\mathrm{T}_{3}, \mathrm{~T}_{4}$ and $\mathrm{T}_{5}$ in the vegetative period (Table 2), 8.67, 8.47 and $8.42 \mathrm{mg} \mathrm{kg}^{-1}$, respectively. The importance of $\mathrm{Mg}$ in photosynthesis and the need of this nutrient to be in adequate amounts for iron absorption from plants, because it is connected to chlorophyll, which gives the leaf its green color (FRAZÃO et al., 2009) is known. According to Oldoni (2009), the relation $\mathrm{K} /(\mathrm{Ca}+$ $\mathrm{Mg}$ ) should be between 0.5 to $1.0 \mathrm{meq}$; values above these can cause necrosis of the tip of the leaves, and lower values may cause discoloration of gerbera petals (botanically, they are ligulated flowers). The relation found in this study for all treatments is above of the indicated: $1.40 ; 1.47 ; 1.67$; 1.33 and 1.47 meq for $\mathrm{T}_{1}, \mathrm{~T}_{2}, \mathrm{~T}_{3}, \mathrm{~T}_{4}$ and $\mathrm{T}_{5}$, respectively. However, no adverse effects on plants due to the high relation $\mathrm{K} /(\mathrm{Ca}+\mathrm{Mg})$ were observed.

Among the biometric parameters evaluated, there was a significant difference only among treatments for the diameter of the plant at 56 DAA and for dry matter of aerial parts at 28 DAA (Table 3).

In appropriate nutrition and fertilizer conditions, the plants have shown a greater number of leaves (NL) and, consequently, the leaf area will be greater for conducting photosynthesis, with an increase in both productivity and quality (MOTA et al., 2011). The NL per plant showed no statistical difference according to treatments. According to Malavolta (2006), the formation of leaves is associated with the nitrogen available to the plant. As noted in Table 1 , $\mathrm{N}$ levels were similar among treatments, assuming that its quantities on treatments were satisfactory for leaf development in evaluation periods. Different gerbera leaf numbers have been reported in studies such as Singh and Mandhar (2001), Ludwig et al. (2010). However, the results vary. This may be related to cultivars, plant's nutritional conditions or even controlled weather inside the greenhouse.

Plant diameter (PD) differed significantly among treatments at 56 DAA (Table 2). $\mathrm{T}_{1}(24.05 \mathrm{~cm}), \mathrm{T}_{3}(21.60$ $\mathrm{cm})$ and $\mathrm{T}_{4}(23.93 \mathrm{~cm})$ showed the highest mean values for this parameter; however, $\mathrm{T}_{3}(21.60 \mathrm{~cm})$ did not differ from $\mathrm{T}_{2}(20.22 \mathrm{~cm})$ and $\mathrm{T}_{5} .(20.65 \mathrm{~cm})$ Higher values for PD $(10.70 \mathrm{~cm})$ in Tiramise and Lyonella cultivars were found by Singh and Mandhar (2001). However, according to Ludwig et al., (2010), plant diameter is a cultivardependent characteristic.

Leaf area was not affected by different fertilizer types used in this study (Table 2). The dry matter of aerial parts (DMAP) differed among treatments at 28 DAA (Table 2). $\mathrm{T}_{1}(4.13 \mathrm{~g})$ had the lowest DMAP, but it did not differentiate from $\mathrm{T}_{2}(4.47 \mathrm{~g}), \mathrm{T}_{3}(4.45 \mathrm{~g})$ and $\mathrm{T}_{5}(4.52 \mathrm{~g})$. As to the evaluations of inflorescences, only the stem height differed significantly among treatments (Table 4$)$. The treatments with LOF $\left(\mathrm{T}_{2}, \mathrm{~T}_{5}\right)$ showed higher mean values of $\mathrm{SH}$ regarding the treatment with mineral fertilizer $\left(\mathrm{T}_{1}\right)$. 
Table 3. Number of leaves (NL), plant diameter (PD), leaf area (LA) and dry matter of aerial parts (DMAP) in gerbera plants grown in mineral fertilizer and liquid organic fertilizer, obtained at 28 and 56 DAA.

Tabela 3. Número de folhas (NF), diâmetro de planta (DP), área foliar (AF) e massa seca da parte aérea (MSPA), em planta de gérberas cultivadas em adubo mineral e adubações orgânicas líquidas, obtidas aos 28 e 56 DAA.

\begin{tabular}{|c|c|c|c|c|c|c|c|c|c|}
\hline & \multicolumn{3}{|c|}{$\mathrm{NL}$} & \multicolumn{2}{|c|}{$\mathrm{PD}(\mathrm{cm})$} & \multicolumn{3}{c|}{ LA $\left(\mathrm{cm}^{2}\right)$} & \multicolumn{2}{|c|}{ DMAP $(\mathrm{g})$} \\
\hline & 28 & 56 & 28 & 56 & 28 & 56 & 28 & 56 \\
\hline $\mathrm{DAA}$ & & & & & & & & \\
\hline $\mathrm{T}_{1}$ & 15.00 & 19.75 & 18.02 & $24.05 \mathrm{a}$ & 298.63 & 683.90 & $4.13 \mathrm{~b}$ & 8.24 \\
\hline $\mathrm{T}_{2}$ & 18.25 & 16.50 & 18.70 & $20.22 \mathrm{~b}$ & 365.33 & 674.67 & $4.47 \mathrm{ab}$ & 7.25 \\
\hline $\mathrm{T}_{3}$ & 20.00 & 22.25 & 18.62 & $21.60 \mathrm{ab}$ & 401.58 & 893.50 & $4.45 \mathrm{ab}$ & 7.77 \\
\hline $\mathrm{T}_{4}$ & 23.25 & 20.00 & 19.27 & $23.93 \mathrm{a}$ & 494.19 & 663.65 & $4.83 \mathrm{a}$ & 8.02 \\
\hline $\mathrm{T}_{5}$ & 17.25 & 17.75 & 19.85 & $20.65 \mathrm{~b}$ & 391.89 & 594.93 & $4.52 \mathrm{ab}$ & 6.60 \\
\hline $\mathrm{CV}(\%)$ & 21.76 & 22.70 & 8.70 & 6.56 & -19.58 & 18.57 & 4.51 & 11.68 \\
\hline $\mathrm{dms}$ & 9.54 & 9.54 & 3.59 & 3.15 & 95.24 & 427.43 & 0.44 & 1.92 \\
\hline
\end{tabular}

Averages followed by the same letter in the column do not differ on Tukey test at 5\% significance level. DAA: days after acclimatization. $\mathrm{T}_{1}$ : commercial substrate: mineral fertilizer (NPK) irrigated with water. $\mathrm{T}_{2}$ : commercial substrate fertilized with composition $\mathrm{T}_{2}$. $\mathrm{T}_{3}$ : commercial substrate fertilized with composition $\mathrm{T}_{3}$. $\mathrm{T}_{4}$ : commercial substrate fertilized with composition $\mathrm{T}_{4} \cdot \mathrm{T}_{5}$ : commercial substrate fertilized with composition $\mathrm{T}_{5}$.

Médias seguidas pela mesma letra na coluna não diferem entre si pelo teste de Tukey ao nível de 5\% de significância. $T_{I}$ : substrato comercial: adubação mineral (NPK) irrigado com água. $T_{2}$ : substrato comercial fertirrigado com composição $T_{2} . T_{3}:$ substrato comercial fertirrigado com composição $T_{3} . T_{4}$ : substrato comercial fertirrigado com composição $T_{4} \cdot T_{5}$ : substrato comercial fertirrigado com composição $T_{5}$

Table 4. Dry matter of inflorescences (IDM), stem height (SH), head diameter (HD) and stem diameter (SD), in gerberas plants grown in mineral fertilizer and liquid organic fertilizer, obtained at 56 DAA.

Tabela 4. Matéria seca de inflorescência (MSI), altura de haste (AH), diâmetro de capitulo (DC) e diâmetro de haste (DH), em planta de gérberas cultivadas em adubo mineral e adubações orgânicas líquidas, obtidas aos 56 DAA.

\begin{tabular}{|c|c|c|c|c|}
\hline & $\begin{array}{c}\text { IDM } \\
\left(\mathrm{g} \text { inflorescence }{ }^{-1}\right)\end{array}$ & $\begin{array}{c}\text { SH } \\
\left(\mathrm{cm} \mathrm{plant}^{-1}\right)\end{array}$ & $\begin{array}{c}\text { HD } \\
\left(\mathrm{mm} \mathrm{head}^{-1}\right)\end{array}$ & $\begin{array}{c}\text { SD } \\
\left(\mathrm{mm} \mathrm{plant}^{-1}\right)\end{array}$ \\
\hline & \multicolumn{4}{|c|}{56 DAA } \\
\hline $\mathrm{T}_{1}$ & 6.97 & $17.55 \mathrm{~b}$ & 86.07 & 4.44 \\
\hline $\mathrm{T}_{2}$ & 7.35 & $22.20 \mathrm{a}$ & 82.90 & 4.46 \\
\hline $\mathrm{T}_{3}$ & 6.65 & $20.32 \mathrm{ab}$ & 88.42 & 4.54 \\
\hline $\mathrm{T}_{4}$ & 7.17 & $18.02 \mathrm{~b}$ & 90.42 & 4.52 \\
\hline $\mathrm{T}_{5}$ & 7.44 & $23.30 \mathrm{a}$ & 79.90 & 4.43 \\
\hline $\mathrm{CV}(\%)$ & 11.89 & 6.89 & 7.24 & 6.43 \\
\hline dms & 1.81 & 3.02 & 13.51 & 0.63 \\
\hline
\end{tabular}

Averages followed by the same letter in the column do not differ on Tukey test at 5\% significance level. DAA: Days after acclimatization. $\mathrm{T}_{1}$ : commercial substrate: mineral fertilizer (NPK) irrigated with water. $\mathrm{T}_{2}$ : commercial substrate fertilized with composition $\mathrm{T}_{2} . \mathrm{T}_{3}$ : commercial substrate fertilized with composition $\mathrm{T}_{3} \cdot \mathrm{T}_{4}$ : commercial substrate fertilized with composition $\mathrm{T}_{4} \cdot \mathrm{T}_{5}$ : commercial substrate fertilized with composition $\mathrm{T}_{5}$.

Médias seguidas pela mesma letra na coluna não diferem entre si pelo teste de Tukey ao nível de 5\% de significância. $T_{1}$ : substrato comercial: adubação mineral (NPK) irrigado com água. $T_{2}$ : substrato comercial fertirrigado com composição $T_{2}$. $T_{3}$ : substrato comercial fertirrigado com composição $T_{3}$. $T_{4}$ : substrato comercial fertirrigado com composição $T_{4} \cdot T_{5}$ : substrato comercial fertirrigado com composição $T_{5}$. 
The number of heads did not show homogeneity of variances, therefore it made the comparison of means impossible. According to the descriptive analysis, the overall mean of all treatments for the number of heads is 2.5. According to Oldoni (2009), $\mathrm{N}$ is an important nutrient in the growth and reproductive phases of gerbera, contributing mainly to the growth of the flower stem. $\mathrm{T}_{4}$ received the least amount of $\mathrm{N}$ during culture cycle $\left(13,500.00 \mathrm{mg} \mathrm{k}^{-1}\right)$ (Table 1), which may have resulted in the lower gerbera plant's stem height (Table 3).

Another classification proposed by IBRAFLOR refers to the plant's quality according to the number of inflorescences per pot, ranging from class I (one inflorescence) to class IV (four inflorescences). Considering the results of this experiment, there were on average two flowers per pot, therefore, class II. Ludwig et al. (2011) analyzed two gerbera cultivars (Red and Cherry) conducted on different substrates and found that the Red cultivar was characterized by being more floriferous when compared to Cherry. The authors found a propensity towards a better acceptance by plants consisted of inflorescences with a larger diameter, even if their number is lower.

Regarding studies of organic fertilizers in gerbera culture, Damasceno et al. (2010), who evaluated the application by fertigation of treated wastewater, can be cited. The authors concluded that there were no changes in the nutritional status of leaves and in the quality of inflorescences of plants receiving wastewater when compared to mineral fertilization. However, $\mathrm{P}, \mathrm{Na}$ and $\mathrm{K}$ concentrations and organic matter in the soil increased when treated with the wastewater.

Some researches with the use of an extra source of organic fertilizer, even if verified significant increases of certain macronutrients plants, recommend a second mineral source with the objective of supplementing nutritional needs. However, according to the results obtained in this study and other studies (MEDEIROS et al., 2007; CERQUEIRA et al., 2008; DAMASCENO et al., 2010), mineral supplement in gerbera nutrition with organic fertilization is not necessary. Organic fertilization, according Damasceno et al. (2010), provides sufficient amounts of nutrients to plants, so that they show a healthy appearance or no symptoms of nutrient deficiency. The current use of organic waste to obtain organic fertilizers is something great for easy handling and lower costs with chemical fertilizers (BRITO and D'OLIVEIRA, 2010), and properly allocate the organic waste producers have saving in the purchase of chemical fertilizers.

\section{CONCLUSION}

Liquid organic fertilizers, obtained by composting procession of poultry slaughter waste, can be used as alternative source for potted gerbera nutrition, since they provide better or higher culture growth than the mineral fertilizer.

\section{ACKNOWLEDGMENTS}

To Agricultural Engineering Graduate Program (PGEAGRI/UNIOESTE) for opportunity. To CAPES for granting Masters Scholarship.

\section{REFERENCES}

BARBOSA, J.G.; BARBOSA, M.S.; MUNIZ, M.A.; CROSSI, J.A.S. Nutrição mineral e adubação de plantas ornamentais. Informe Agropecuário, Belo Horizonte, v.30, n.249, p. 16-21, 2009.

BRITO, L.R.; D'OLIVEIRA, P.S. Uso de resíduos sólidos urbanos na produção de flores e plantas ornamentais. Revista de Agronegócios e Meio Ambiente, Maringá, v.3, n.2, p.67-77, 2010.

CABAllero, R.; PAJUElO, P.; ORDOVA, J.; CARMOSA, E.; DELGADO, A. Evaluation and correction of nutriente availability to Gerbera jamesonii $\mathrm{H}$. Bolus in various compost-based growing media. Scientia Horticulturae, Amsterdam, v.122, n.2, p.244-250, 2009.

CARDOSO, J.C.; SILVA, J.A.T. Gerbera micropropagation. Biotechnology Advances, Rehovot, v.31, n.8, p.13441357, 2013.

CASTRO, A.M.C.; SILVA, S.C.; PAULETTI, D.R.; SPACKI, A.P.; VACARIN, R.N.D.; SILVA, L.P.E.; DARTORA, J. Resíduos orgânicos no cultivo de crisântemo e em alguns atributos físicos do solo. Agrarian, Dourados, v.1, n.1, p.21-35, 2008.

CASTRO, A.M.C.; SATO, O.; SANTOS, K.H.; ZAPOLLI, R.A.; SARTORI, S.B.; DEMÉTRIO, G.B. Adubação mineral e orgânica no desenvolvimento de crisântemo. Semina: Ciências Agrárias, Londrina, v.31, n.1, p.93-100, 2010 .

CERQUEIRA, L. L.; FADIGAS, F.S.; PEREIRA, F.A.; GLOAGUEN, T.V.; COSTA, J.A. Desenvolvimento de Heliconia psittacorum e Gladiolus hortulanus irrigados com águas residuárias tratadas. Revista Brasileira de Engenharia Agrícola e Ambiental, Campina Grande, v.12, n.6, p.606-613, 2008.

DAMASCENO, L.M.O; ANDRADE JÚNIOR, A.S.; GHEYI, H.R.; RIBEIRO, V.Q.; DIAS, N.S. Cultivation of gerbera irrigated with treated domestic effluents. Revista Brasileira de Engenharia Agrícola e Ambiental, Campina Grande, v.14, n.6, p.582-588, 2010.

EMBRAPA. Manual de análises químicas de solos, plantas e fertilizantes. Brasília: EMBRAPA, 2009. 627 p. FRAZÃO, J.E.M.; PINHO, P.J.; ALMEIDA, E.F.A.; 
CARVALHO, J.G.; PAIVA, P.D.O. Sintomas visuais de deficiência nutricional em plantas ornamentais. Informe Agropecuário, Belo Horizonte, v.30, n.249, p.23-32, 2009.

GUERRERO, A.C.; FERNANDES, D.M.; LUDWIG, F. Acúmulo de nutrientes em gérbera de vaso em função de fontes e doses de potássio. Horticultura Brasileira, Brasília, v.30, n.2, p. 201-208, 2012.

HERNÁNDEZ, A.; CASTILLO, H.; OJEDA, D.; ARRAS, A.; LÓPEZ, J.; SÁNCHEZ, E.; Effect of vermicompost and compost on lettuce production. Chilean Journal of Agricultural Research, Chillán, v.70, n. 4, p.583-589, 2010.

INFOAGRO. El cultivo de la gerbera. 2014. Disponível em:

$<$ http://www.infoagro.com/flores/flores/gerbera.htm>. Acesso em: 02 de fevereiro 2014.

JEONG, K.Y.; WHIPKER, B.; McCALL, I.; GUNTER, C.; FRANTZ, J. Characterization of nutrient disorders of gerbera hidrid "Festival light Eye Pink". Acta Horticulturae, Wageningen, v.843, n.843, p.177-182, 2009.

LONGCHAR, A.; KEDITSU, R. Flower yield and vase life of Gerbera in response to planting time and organic manures on Alfisol. Scientific Journal of Agricultural, Toronto, v.2, n.3, p.124-128, 2013.

LUDWIG, F.; FERNANDES, D.M.; MOTA, P.R.D; VILLAS BÔAS, R.L. Macronutrientes em cultivares de gérbera sob dois níveis de fertirrigação. Horticultura Brasileira, Brasília, v.26, n.1, p.68-73, 2008.

LUDWIG, F.; FERNANDES, D.M.; MOTA, P.R.D.; VILLAS BÔAS, R.L. Crescimento e produção de gérberas fertirrigadas com solução nutritiva. Horticultura Brasileira, Brasília, v.28, n.4, p.424-429, 2010.

LUDWIG, F.; GUERREIRO, A.C.; FERNANDES, D.M.; VILLAS BÔAS, R.L.; LASCHI, D. Qualidade de cultivares de gérbera de vaso em função das características físicas e químicas dos substratos. Revista Brasileira de Horticultura Ornamental, Campinas, v.17, n.2, p.141148, 2011.

LUDWIG, F.; FERNANDES, D.M.; GUERRERO, A.C.; VILLAS BÔAS. R.L. Metodologias para monitoramento nutricional de gérberas cultivadas em substratos. Revista Brasileira de Horticultura Ornamental, Campinas, v.21, n.1, p.77-84, 2015.

MALAVOLTA, E.; VITTI, G.C.; OLIVEIRA, S.A. Avaliação do estado nutricional das plantas. 2.ed. Piracicaba: Potafos. 1997. 319 p.

MALAVOLTA, E. Elementos de nutrição mineral de plantas. São Paulo: Agronômica Ceres. 2006. 253 p.

MEDEIROS, S.S.; SOARES, F.A.L.; GHEYI, H.R.;
FERNANDES, P.D. Uso de água residuária de origem urbana no cultivo de gérberas: efeitos nos componentes de produção. Engenharia Agrícola, Jaboticabal, v.27, n.2, p.569-578, 2007.

MERCURIO, G. Gerbera cultivation in greenhouse. The Netherlands: Schreurs, 2002. 206p.

MOTA, P.R.D.; VILLAS BÔAS, R.L.; LUDWIG, F.; FERNANDES, D.M.; FOLEGATTI, M.V. Avaliação do pH e condutividade elétrica em substrato sob diferentes níveis de fertirrigação e métodos de extração da solução. Revista Brasileira de Horticultura Ornamental, Campinas, v.17, n.2, p.121-126, 2011.

OLDONI, C.M. Produção de gérberas. Informe Agropecuário, Belo Horizonte, v.30, n.249, p.67-73, 2009.

R Development Core Team. R: a language and environment for statistical computing. R Foundation for Statistical Computing, Vienna, Austria. ISBN 3-90005107-0. Disponível em: <http://www.R-project.org/> Acesso em: 20 de dezembro 2011.

RUPPENTHAL, V.; CASTRO, A.M.C. Efeito do composto de lixo urbano na nutrição e produção de gladíolo. Revista Brasileira de Ciência do Solo, Viçosa, v.29, n.1, p.145$150,2005$.

SAVVAS, D.; GIZAS, D.G. Response of hydroponically grown gerbera to nutrient solution recycling and different nutrient cations ratios. Scientia Horticulturae, Amterdam, v.96, n.1, p. 267-280, 2002.

SCHACHTMAN, D.P.; REID, R.J.; AYLING, S.M. Phosphorus uptake by plants: from soil to cell. Plant Physiology, Baltimore, v.116, n.2, p.447-453, 1998.

SINGH, K.P.; MANDHAR, S.C. Performance of exotic cultivars of gerbera (Gerbera jamesonii) under low cost naturally ventilated greenhouse environment. Indian Journal of Agricultural Sciences, New Delhi, v.71, n.4, p.244-248, 2001.

STANCATO, G. C. Gérbera. Disponível em: $<$ http://revistagloborural.globo.com/Revista/ Common/0,,ERT168359-18293,00.html> Acesso em: 05 de fevereiro 2014.

TEDESCO, M.J.; GIANELLO, C.; BISSANI, C. A.; BOHNEN, H.; WOLKWEISS, S.J. Análise de solo, plantas e outros materiais. 2.ed., Porto Alegre: Universidade Federal do Rio Grande do Sul, 1995. 174 p.

ZHENG, Y.; THOMAS, G.; STEFAN, R.; MIKE, D. Potted gerbera production in a subirrigation system using lowconcentration nutrient solutions. HortScience, Alexandria, v.39, n.6, p.1283-1286, 2004. 